\title{
Revisiting the Spawning Pattern of Nyale Worms (Eunicidae) Using the Metonic Cycle
}

\author{
Imam Bachtiar ${ }^{1,2, *}$ and Shingo Odani ${ }^{3}$
}

\author{
${ }^{1}$ Department of Math and Sciences Education, Faculty of Teacher Training and Education, University of Mataram \\ 2Master of Science Education Study Program, Postgraduate Program, University of Mataram \\ J. Majapahit No.62, Selaparang, Mataram, Nusa Tenggara Barat, 83115 Indonesia \\ 3Faculty of Letters, Chiba University \\ 1-33 Yayoi-cho, Inage-ku, Chiba-shi, Chiba 263-8522 Japan \\ Email: imambachtiar@unram.ac.id
}

\begin{abstract}
Mass spawning dates of nyale worms (Eunicidae) have been scientifically predictable since 2019. However, the prediction of split spawning, i.e. the phenomenon when nyale worms spawn in both February and March, was made based on limited data. The present study aimed to revisit the dates of the split spawning prediction using the Metonic Cycle, i.e. 19-year lunisolar cycle. Using the existing prediction method 114 years of prediction dates were generated and then matched the dates with the Metonic Cycle. The results show that the spawning prediction dates generally follow the Metonic Cycle. There are only a few dates that need to be revised, i.e. when the full moon rises on the $14^{\text {th }}$ of February. It is suggested that split spawning of worms is likely to occur when the full moon rises between the $7^{\text {th }}$ to $13^{\text {th }}$ of February. When the full moon appears before the $7^{\text {th }}$ of February, single spawning will take place on the fifth day after March's full moon. When the full moon occurs after the $13^{\text {th }}$ of February, single spawning will occur on the fifth day after February's full moon. The present work is the first study that demonstrates the relationship between nyale worms' spawning patterns and the Metonic Cycle.
\end{abstract}

Keywords: bau nyale, Lombok, Polychaete, swarming, cultural tourism, prediction, hypothesis

\section{Introduction}

Mass spawning of nyale worms (Eunicidae, Polychaeta) is a very important annual event for Lombok people. Nyale worms are multiple species that are mainly composed of Palola (Eunice) sp. and Lycidice sp. (Jekti et al., 1993). Although the Nereididae worms also swarm at the same time as the Eunicidae, they are not considered as the nyale worms. Lombok people neither collect nor consume the nereidid worms. The nyale worms release their generative body parts or epitokes simultaneously that the water contains plenty of epitokes. The swarming epitokes or nyale (in Sasak, Lomboker tribe language) have been foraged for centuries by coastal communities for their free delicacies. The tradition of bau nyale (foraging epitokes) has been promoted as one of the biggest cultural festivals of Indonesia (Triyanti et al., 2020; Taqwiem et al., 2020) and attracting tens of thousands of visitors. As the peak of spawning occurs in one night, the prediction of the mass spawning is crucial to satisfy the visitors of the annual cultural festival. Traditionally, the prediction was only made by cultural leaders in a sacred ritual meeting (Odani et al., 2016). A similar traditional prediction also applies to nyale worms on Sumba Island (Furusawa and Siburian, 2019), laor worms on
Ambon Island (Mahulette, 2020), and palolo worms on Samoa (Lefale, 2010). All these worms are referred to Eunicidae worms releasing epitokes, particularly Palola spp. and Lysidice spp.

In 2019, the first scientific prediction was introduced for nyale worms (Bachtiar and Bachtiar, 2019). The prediction enables all people to make predictions provided that they have access to the date of February's full moon of a particular year. In many marine invertebrates, the moon cycle is strongly linked with the date of spawning (Willis et al., 1985; Wolstenholme et al., 2018; Vélez-Arellano et al., 2020), while the annual sea temperature cycle coincides with the month of spawning (Babcock et al., 1985; Nozawa, 2012; Caballes and Pratchett, 2017), and the tidal cycle is related to the time of spawning (Willis et al., 1985; Darnell et al., 2012; Collin et al., 2017). A one hundred years spawning prediction of nyale worms generated in Bachtiar and Bachtiar (2019) showed a higher accuracy than the traditional one. In the last 14 years, its accuracy was 100\%, while traditional prediction was missed three times in the last six years. The scientific prediction is based on both lunar and solar cycles. Bachtiar and Bachtiar (2019) suggested three hypotheses: First, when the full moon occurs before the $7^{\text {th }}$ of February, the
*) Corresponding author

(C) IImu Kelautan, UNDIP https://ejournal.undip.ac.id/index.php/ijms DOI: 10.14710/ik.ijms.26.2.87-94
Received : 11-03-2021

Accepted : 27-05-2021 
spawning of worms will take place on the fifth day after the full moon of March (20 th lunar calendar). Second, when the full moon rises between the $7^{\text {th }}$ and $14^{\text {th }}$ February, the spawning will take place twice, i.e. on the fifth day after the full moon of February $\left(20^{\text {th }}\right.$ lunar calendar) and the fifth day after the full moon of March. Third, when the full moon occurs after the $14^{\text {th }}$ of February, the spawning will occur on the fifth day after the full moon of February.

Inspite of its high accuracy, the second hypothesis has not been tested yet in the field. The period that leads to split spawning is considered as critical dates in Bachtiar and Bachtiar (2019) due to lack of available data and is hardly proven until the time comes. The full moon on the $7^{\text {th }}$ of February will occur in 2031, and the full moon on the $14^{\text {th }}$ of February will rise in 2033 (www.timeanddate.com). Casper (1984) found some periods with uncertain spawning events when he studied spawning periodicities of palolo worms in Samoa. He also noticed that there was a 19-year cycle, in 1940 and 1959 , in which the date of spawning was the same on the $24^{\text {th }}$ of October. The 19-years cycle (or 18.6 years to be exact) has been long identified in a lunisolar cycle that is well known as the Metonic Cycle. The cycle is strongly related to tidal cycles (Currie and Fairbridge, 1985; Yasuda, 2018) and may provide the best foundation to test and strengthen the second hypothesis of Bachtiar and Bachtiar (2019).

The present study aimed to revisit the spawning pattern of nyale worms using the 19-year Metonic Cycle. As the scientific prediction is not yet available for laor worms in Maluku, palolo worms in Samoa, the results of the study may also apply or at least adaptable to those worms, since nearly all of them belong to the Family Eunicidae and Nereididae. In the central and western Pacific, the month of spawning is October or November, while in the eastern Indian Ocean the month of spawning is February or March.

\section{Materials and Methods}

To match the scientific prediction of nyale worms' spawning dates with the patterns of the Metonic Cycle (19-years), an existing 100 years (2000-2100) spawning prediction dates in Bachtiar and Bachtiar (2019) were revisited to find a pattern of the Metonic Cycle. The prediction dates were developed from available spawning date records in four years (2015-2018) and validated using eight years data (2007-2014) from online media and amateur writers on electronic materials (blogs, Youtube). Full moon dates were obtained from www.timeanddate.com. Despite its relatively small number of data used to construct the hypotheses, the prediction has 100\% accuracy from 2007 to 2021.
The 19-year cycles were detected in the periods of 2001-2019, 2020-2038, 2039-2057, 2058-2076, and 2077-2095 (Table 1). The prediction dates were then extended to the year 2114 to obtain six full Metonic Cycles. The prediction dates were reviewed for any patterns of coincidence or violations to the six Metonic Cycles. It was expected that the occurrence pattern of the split spawning is consistently match up with the 19-years cycle, and the same spawning dates reoccur every 19 years.

\section{Result and Discussion}

The Metonic Cycle shows the orderly occurrence of split- and single- spawnings. In each cycle, 5 (five) split spawning and 14 single spawnings are identified. The pattern of spawnings in a single cycle (19 years) may be described as 1-4-1-2-1-2-1-4$1-2$. Numbers 1 represent split spawnings, whereas numbers 2 and 4 represent single spawnings. The spawning type composition of nyale worms based on the Metonic Cycle is 1 split spawning followed by 4 single spawnings, then 1 split spawning tracked by 2 single spawnings, and another 1 (one) split spawning followed by 2 single spawnings, and back to 1 split spawning and 4 single spawnings. The 19 -year cycle is finally closed by the occurrence of 1 split spawning followed by 2 single spawnings. This pattern is consistent from 2001 to 2114 (114 years), which consists of six cycles.

The split spawning pattern of nyale worms is different from that of corals. A decade observation on the coral spawning in Scott Reefs (Western Australia) showed that split spawnings occurred more frequently every two or three years (Foster et al., 2018). The coral split spawning occurred in 2007 , 2010, 2013, and 2015. During the same period (2007-2016), nyale worms demonstrated split spawning only twice, i.e. in 2009 and 2012. A combination of single and split spawnings may increase the variation of larval supply and enhance inter-reef connectivity (Hock et al., 2019).

The Metonic Cycle also shows a repeated pattern of months of single spawnings. In the case of two consecutive single spawnings, the order month of spawning is consistently in March and then February. In the case of four consecutive single spawnings, the general order is also March - February - March February. There are two cycles, however, in which the first period of four consecutive single spawnings does not seem to follow this general rule. In the cycles of 2001-2019 and 2039-2057, the month order of the first four consecutive single spawnings is MarchFebruary-March-March. The difference occurs in the $5^{\text {th }}$ year of the cycles. In fact, in all the $5^{\text {th }}$ years of the cycles, all nyale worms spawn after the full moon of February. Since the full moon occurs in late February 
ILMU KELAUTAN: Indonesian Journal of Marine Sciences June 2021 Vol 26(2):87-94

Table 1. Observed and predicted spawning patterns of nyale worms at the southern coast of Lombok Island. Grey cells show split spawning.

\begin{tabular}{|c|c|c|c|c|c|c|c|c|c|c|c|c|}
\hline No & Year & *Fm Feb & Fm Mar & Spawning Date & Year & Fm Feb & Fm Mar & Spawning Date & Year & Fm Feb & Fm Mar & Spawning Date \\
\hline 1 & 2001 & 8 & 10 & 13 Feb and 15 Mar* & 2020 & 9 & 10 & 14 Feb and 15 Mar* & 2039 & 9 & 11 & 14 Feb and 16 Mar* \\
\hline 2 & 2002 & 27 & 29 & 04-Mar & 2021 & 27 & 29 & 04-Mar & 2040 & 28 & 28 & 05-Mar \\
\hline 3 & 2003 & 17 & 18 & 22-Feb & 2022 & 17 & 18 & 22-Feb & 2041 & 16 & 18 & 21-Feb \\
\hline 4 & 2004 & 6 & 7 & 12-Mar & 2023 & 6 & 7 & 12-Mar & 2042 & 5 & 7 & 12-Mar \\
\hline 5 & 2005 & 24 & 26 & 01-Mar & 2024 & 24 & 25 & 29-Feb & 2043 & 24 & 25 & 01-Mar \\
\hline 6 & 2006 & 13 & 15 & 18 Feb and 20 Mar & 2025 & 12 & 14 & 17 Feb and 19 Mar & 2044 & 13 & 14 & 18 Feb dan 19 Mar \\
\hline 7 & 2007 & 2 & 4 & 09-Mar & 2026 & 2 & 3 & 08-Mar & 2045 & 2 & 3 & 08-Mar \\
\hline 8 & 2008 & 21 & 22 & 26-Feb & 2027 & 21 & 22 & 26-Feb & 2046 & 21 & 22 & 26-Feb \\
\hline 9 & 2009 & 9 & 11 & 14 Feb and 16 Mar & 2028 & 10 & 11 & 15 Feb and 16 Mar & 2047 & 10 & 12 & $15 \mathrm{Feb}$ and $17 \mathrm{Mar}$ \\
\hline 10 & 2010 & - & $\begin{array}{c}1 \text { and } \\
30\end{array}$ & 06-Mar & 2029 & - & $\begin{array}{c}1 \text { and } \\
30\end{array}$ & 06-Mar & 2048 & 29 & 30 & 05-Mar \\
\hline 11 & 2011 & 18 & 20 & 23-Feb & 2030 & 18 & 20 & 23-Feb & 2049 & 18 & 19 & 23-Feb \\
\hline 12 & 2012 & 8 & 8 & 13 Feb and 13 Mar & 2031 & 7 & 9 & 12 Feb and $14 \mathrm{Mar}$ & 2050 & 7 & 8 & 12 Feb and $15 \mathrm{Mar}$ \\
\hline 13 & 2013 & 26 & 27 & 03-Mar & 2032 & 26 & 27 & 03-Mar & 2051 & 25 & 27 & 02-Mar \\
\hline 14 & 2014 & 15 & 17 & 20-Feb & 2033 & 14 & 16 & $19 \mathrm{Feb}^{* *}$ & 2052 & 15 & 15 & 20-Feb \\
\hline 15 & 2015 & 4 & 6 & 11-Mar & 2034 & 3 & 5 & 10-Mar & 2053 & 3 & 5 & 10-Mar \\
\hline 16 & 2016 & 23 & 23 & 28-Feb & 2035 & 22 & 24 & 27-Feb & 2054 & 22 & 24 & 27-Feb \\
\hline 17 & 2017 & 11 & 12 & 16 Feb and 17 Mar & 2036 & 12 & 12 & 17 Feb and 17 Mar & 2055 & 12 & 13 & $17 \mathrm{Feb}$ and $18 \mathrm{Mar}$ \\
\hline 18 & 2018 & - & $\begin{array}{c}2 \text { and } \\
31\end{array}$ & 07-Mar & 2037 & - & $\begin{array}{c}2 \text { and } \\
31\end{array}$ & 07-Mar & 2056 & 1 & 2 & 07-Mar \\
\hline 19 & 2019 & 19 & 21 & 24-Feb & 2038 & 20 & 21 & 25-Feb & 2057 & 19 & 21 & 24-Feb \\
\hline
\end{tabular}

Notes: *Start of the Metonic Cycle. **It was previously predicted to be split spawning. ***It was previously predicted to be single spawning (Bachtiar and Bachtiar, 2019). 
ILMU KELAUTAN: Indonesian Journal of Marine Sciences June 2021 Vol 26(2):87-94

Table 1. Observed and predicted spawning patterns of nyale worms at the southern coast of Lombok Island. Grey cells show split spawning (Continued)

\begin{tabular}{|c|c|c|c|c|c|c|c|c|c|c|c|c|}
\hline No & Year & *Fm Feb & Fm Mar & Spawning Date & Year & Fm Feb & Fm Mar & Spawning Date & Year & Fm Feb & Fm Mar & Spawning Date \\
\hline 1 & 2058 & 8 & 10 & 13-Feb and 15-Mar* & 2077 & 8 & 10 & 13-Feb and 15-Mar* & 2096 & 8 & 9 & 13-Feb and 14-Mar* \\
\hline 2 & 2059 & 27 & 29 & 04-Mar & 2078 & 27 & 28 & 04-Mar & 2097 & 26 & 28 & 03-Mar \\
\hline 3 & 2060 & 16 & 17 & 21-Feb & 2079 & 16 & 17 & $21 \mathrm{Feb}$ & 2098 & 16 & 17 & 21-Feb \\
\hline 4 & 2061 & 4 & 5 & 10-Mar & 2080 & 5 & 6 & 11-Mar & 2099 & 5 & 7 & 12-Mar \\
\hline 5 & 2062 & 23 & 25 & 28-Feb & 2081 & 23 & 25 & 28-Feb & 2100 & 24 & 26 & 29-Feb \\
\hline 6 & 2063 & 13 & 15 & 20-Feb and 20-Mar & 2082 & 13 & 15 & 18-Feb and 20-Mar & 2101 & 14 & 15 & 19-Feb \\
\hline 7 & 2064 & 3 & 3 & 08-Mar & 2083 & 3 & 4 & 09-Mar & 2102 & 3 & 5 & 10-Mar \\
\hline 8 & 2065 & 21 & 22 & 26-Feb & 2084 & 22 & 22 & 27-Feb & 2103 & 22 & 24 & 27-Feb \\
\hline 9 & 2066 & 10 & 12 & 15-Feb and 17-Mar & 2085 & 10 & 11 & 15 Feb and 16 Mar & 2104 & 11 & 12 & 16-Feb and 17-Mar \\
\hline 10 & 2067 & -- & $\begin{array}{c}1 \text { and } \\
31\end{array}$ & 06-Mar & 2086 & 28 & 30 & 05-Mar & 2105 & -- & 1 & 06-Mar \\
\hline 11 & 2068 & 18 & 19 & 23-Feb & 2087 & 17 & 19 & 22-Feb & 2106 & 18 & 20 & 23-Feb \\
\hline 12 & 2069 & 6 & 8 & 11-Feb and 13-Mar*** & 2088 & 7 & 7 & 12-Feb and 12-Mar & 2107 & 8 & 9 & 13-Feb and 14-Mar \\
\hline 13 & 2070 & 25 & 27 & 02-Mar & 2089 & 25 & 26 & 02-Mar & 2108 & 27 & 27 & 03-Mar \\
\hline 14 & 2071 & 14 & 16 & $19 \mathrm{Feb}^{* * *}$ & 2090 & 14 & 16 & $19 \mathrm{Feb}^{* *}$ & 2109 & 15 & 17 & 20-Feb \\
\hline 15 & 2072 & 4 & 4 & 09-Mar & 2091 & 4 & 5 & 10-Mar & 2110 & 5 & 6 & 11-Mar \\
\hline 16 & 2073 & 22 & 24 & 27-Feb & 2092 & 23 & 24 & 28-Feb & 2111 & 24 & 25 & 01-Mar \\
\hline 17 & 2074 & 12 & 13 & 17-Feb and 18-Mar & 2093 & 11 & 13 & 16-Feb and 18-Mar & 2112 & 13 & 13 & 18-Feb and 18-Mar \\
\hline 18 & 2075 & 1 & 3 & 08-Mar & 2094 & -- & 2 & 07-Mar & 2113 & 1 & 2 & 07-Mar \\
\hline 19 & 2076 & 20 & 21 & 25-Feb & 2095 & 19 & 21 & 24-Feb & 2114 & 20 & 21 & 25-Feb \\
\hline
\end{tabular}

Notes: *Start of the Metonic Cycle. **It was previously predicted to be split spawning. ***It was previously predicted to be single spawning (Bachtiar and Bachtiar, 2019). 
(2005 and 2043), the 20th lunar calendar of February of both years takes place on the $1^{\text {st }}$ March.

In some cases, the Metonic Cycle indicates repeated spawning dates, as suggested by Casper (1984). Prediction data on single- and splitspawnings over the six cycles revealed that no spawning date prediction has the same date across all the six cycles. All the spawning dates, however, are closely related, with a slight difference of only one or two days (Table 1). For example, in the second year of the cycles, the predicted spawning dates are the $4^{\text {th }}$ of March (2002, 2021, 2059, 2078), $3^{\text {rd }}$ of March (2097), and $5^{\text {th }}$ of March (2040). In this case, it is recorded four spawning dates that are in agreement and two spawning dates that are not in agreement with the Metonic Cycle. Of 84 single spawning dates in the six cycles, 52 spawning dates (63\%) are in agreement with the same order of years in other cycles, whereas the other 31 dates (37\%) are not.

The Metonic Cycle of the nyale worm spawning pattern suggests revising the second of the prediction hypothesis in Bachtiar and Bachtiar (2019). The hypothesis suggests that split spawnings typically occur when the full moon rises between the $7^{\text {th }}$ and $14^{\text {th }}$ of February. This hypothesis, in some cases, is not compatible with the Metonic Cycle. There are four years in which the spawning prediction dates do not match with the Metonic Cycle. In 2069, for instance, the full moon occurs on the $6^{\text {th }}$ of February, but the Metonic Cycle indicates split spawning (Table 1). In 2071, 2090, and 2090, the full moons are on the $14^{\text {th }}$ of February, but the Metonic Cycle suggests single spawning. The hypothesis, therefore, needs to be revised; the predicted spawning dates should be moved one day in advance to fit with the Metonic Cycle. Thus the revised second hypothesis is that the split spawning of nyale worms will occur when the full moon rises between the $7^{\text {th }}$ and $13^{\text {th }}$ of February (Figure 1). This revision does not change the practical use of the existing scientific method.

The revised hypothesis makes the spawning prediction almost entirely fit with the 19-year Metonic Cycle, despite a number of inconsistencies found in 2069 and 2101. Table 2 shows the inconsistencies in the predicted spawning dates when the full moon occurs on the $6^{\text {th }}$ and $14^{\text {th }}$ of February. In the $14^{\text {th }}$ February's full moon cases, the inconsistency may be explained by looking at the full moon rising time. When the full moon rises before 12:00 (noon), the $14^{\text {th }}$ of February 2101 is still considered as the $13^{\text {th }}$ February, that nyale worms will perform split spawning. This speculation, however, does not apply to the inconsistency that occurred on the $6^{\text {th }}$ of February 2069. The anomalies generally indicate that predicting the spawning dates of nyale worms is not very simple; this may also be a correction of the 19year cycle from 18.6 years tidal cycle.

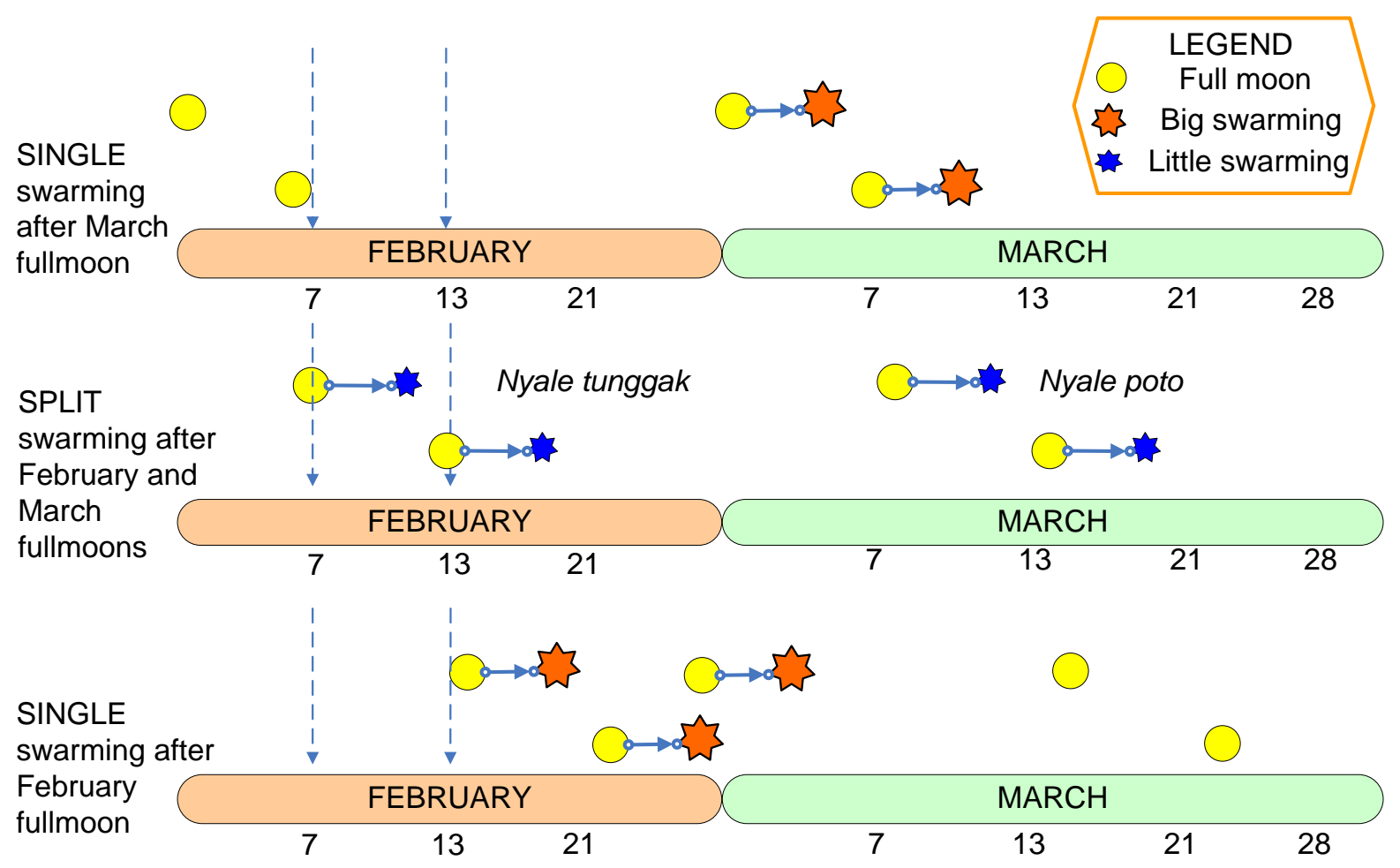

Figure 1. Illustration of three hypotheses to predict the spawning date of nyale worms in Lombok Island. A revision was made on the $13^{\text {th }}$ of February's full moon. 
ILMU KELAUTAN: Indonesian Journal of Marine Sciences June 2021 Vol 26(2):87-94

Table 2. Inconsistencies of predicted spawning dates using the Metonic Cycle

\begin{tabular}{lllll}
\hline Year & February's full moon & March's full moon & Spawning Date & Full Moon Time \\
\hline 2004 & 6 & 7 & $12-$ Mar & $16: 46$ \\
2023 & 6 & 7 & 12-Mar & $02: 28$ \\
2069 & 6 & 8 & *SS 11 Feb and 13 Mar & $13: 29$ and 06:35 \\
\hline 2033 & 14 & 16 & $19-F e b$ & $15: 04$ \\
2071 & 14 & 16 & $19-F e b$ & $21: 33$ \\
2090 & 14 & 16 & $19-F e b$ & $21: 40$ \\
2101 & 14 & 15 & SS 19 Feb and 20 Mar & $10: 44$ and 23:51 \\
\hline
\end{tabular}

*SS: split spawning

It should be noted that there could be more than one date of February's full moon since lunar calendars have different methods of calculation (Tsumura, 2012). In Indonesia, for example, there are Hijri (Islamic), Rowot (Sasak, Lombok tribe), Balinese, Javanese, and Chinese calendars. In the last five years, these lunar calendars have been inaccurate for predicting the spawning peak of nyale worms. The lunar calendar that available on the internet (www.timeanddate.com) has been proven to be accurate for the prediction. This may explain how traditional leaders could miss one day or one month in their spawning prediction. Although they already did the prediction for decades, they did not have access to the international lunar calendar. As a result, the predicted spawning dates made by them sometimes do not match with the actual cycle.

Patterns of mass spawning have been recognized in many marine invertebrates. Multispecific coral mass spawning has been reported in the Great Barrier Reefs (Willis et al., 1985; Hock et al., 2019), Scott Reefs-Australia (Foster et al., 2018), Okinawa Islands (Yamano et al., 2020), and Indonesia (Wijayanti et al., 2019). Multispecies mass spawning of polychaete worms have been described in Samoa (Casper, 1984), the Great Barrier Reefs (Hutchings and Howitt, 1988), Ambon-Indonesia (Pamungkas, 2015; Pamungkas and Glasby, 2019), and Lombok-Indonesia (Bachtiar and Bachtiar, 2019). Prentiss (2020) reported that polychaete worms in the US Virgin Islands do not have multispecies mass spawning, and none of these worms belonged to the family Eunicidae. The date of annual mass spawning may indicate the optimum condition for reproduction (Foster et al., 2018). The mass spawning invertebrates have been evolved for millions of years to get the right time for their reproduction (Willis et al., 2006). The spawning dates of nyale worms are nevertheless the result of such a long evolutionary process that eventually maximizes reproductive outputs. Different reproduction schedules between nyale (Bachtiar and Bachtiar, 2019) and laor worms (Pamungkas, 2015) may be assigned to different environmental factors required by the worms to spawn.
It is still uncovered, however, how these oceanic and climate cycles affect the spawning pattern of nyale worms. At present, no studies are linking marine invertebrate reproduction to the Metonic Cycle. The Metonic Cycle has been reported to associate with oceanographic- (Currie and Fairbridge, 1985; Baart et al., 2012; Peng et al., 2019) and climate- cycles (Yasuda, 2018; Osafune et al., 2020). Spawning time and season may be related to annual cycles of food abundance for larval growth and development and environmental conditions most suitable for larval survival.

The spawning prediction date in the present work needs to be reviewed at least once in a decade since climate change rapidly increases seawater temperature in geological time. In other marine invertebrates, spawning synchrony and dates could change due to climate change. Coral mass spawning has been reported to be accurately predictable with high synchrony (Willis et al., 1985). In recent years, however, several corals showed decreasing spawning synchrony in the Red Sea (Fogarty and Maharver, 2019; Shlesinger and Loya, 2019). Repeated coral bleaching events that resulted in coral mass mortality were suggested to be the main disrupting factor in the spawning synchrony. Unlike corals, climate change does not have direct effects on nyale worms' survivorships. The worms' spawning synchrony might therefore be unaltered in the next several decades. Although the synchrony may not change, increasing seawater temperature may accelerate the gamete maturation of nyale worms that could change the day or month of spawning. Sakai et al. (2020) reported a one-day deviation of coral spawning due to changes in sea surface temperature and wind speed. Such changes may also occur to the spawning cycles of nyale worms.

\section{Conclusion}

Predicted spawning patterns of nyale worms over more than one century are mostly in agreement with the Metonic Cycle. There are only two occasions in 114 years when the dates of spawnings defy the Metonic cycle. This concurrence was used to revise the second hypothesis of Bachtiar and Bachtiar 
(2019). Split spawning in two consecutive months, i.e. February and March, occurs when the full moon rises between the $7^{\text {th }}$ and $13^{\text {th }}$ of February.

\section{Acknowledgment}

I would like to thank Ms. Indah Juanita (BOP Borobudur Park) for her support during the initiation of this work when she was in the Mandalika Resort Office. I want to extend my gratitude to Dr. Karnan and Mr. Lalu Japa for their supporting comments during the progress of the study. Two anonymous reviewers have significant contributions to improve the quality of the manuscript.

\section{References}

Baart, F., Van Gelder, P.H., De Ronde, J., Van Koningsveld, M. \& Wouters, B. 2012. The effect of the 18.6-year lunar nodal cycle on regional sea-level rise estimates. J. Coastal. Res., 28(2):511-516. doi: 10.2112/JCOAST RES-D-11-00169.1

Bachtiar, I. \& Bachtiar, N.T. 2019. Predicting spawning date of nyale worms (Eunicidae, Polychaeta) in the southern coast of Lombok Island, Indonesia. Biodiversitas J. Biol. Divers., 20(4):971-977. doi: 10.13057/biodiv/d20040 6

Caballes, C.F. \& Pratchett, M.S. 2017. Environmental and biological cues for spawning in the crown-ofthorns starfish. Plos One, 12(3):e0173964. doi: 10.1371/journal.pone.0173964

Caspers, H. 1984. Spawning periodicity and habitat of the palolo worm Eunice viridis (Polychaeta: Eunicidae) in the Samoan Islands. Mar. Biol., 79(3):229-236. doi: 10.1007/BF003932 54

Collin, R., Kerr, K., Contolini, G. \& Ochoa, I. 2017. Reproductive cycles in tropical intertidal gastropods are timed around tidal amplitude cycles. Ecol. Evol., 7(15):5977-5991. doi: 10.10 02/ece3.3166

Currie, R.G. \& Fairbridge, R.W. 1985. Periodic 18.6year and cyclic 11-year induced drought and flood in northeastern China and some global implications. Quat. Sci. Rev., 4(2):109-134. doi: 10.1016/0277-3791(85)90016-2

Darnell, M.Z., Wolcott, T.G. \& Rittschof, D. 2012. Environmental and endogenous control of selective tidal-stream transport behavior during blue crab Callinectes sapidus spawning migrations. Mar. Biol., 159:621-631. doi: 10.10 07/s00227-011-1841-1
Fogarty, N.D. \& Marhaver, K.L. 2019. Coral spawning, unsynchronized. Science, 365(6457):987-988. doi: $10.1126 /$ science.aay 7457

Foster, T., Heyward, A.J. \& Gilmour, J.P. 2018. Split spawning realigns coral reproduction with optimal environmental windows. Nat. Commun., 9:718. doi: 10.1038/s41467-01803175-2

Furusawa, T. \& Siburian, R. 2019. Do traditional calendars forecast vegetation changes in Western Sumba, Indonesia? Analyses of indigenous intercalation methods and satellite time-series data. People Cult. Oceania, 35:1-30. doi: 10.32174/jsos.35.0_1

Hock, K., Doropoulos, C., Gorton, R., Condie, S.A. \& Mumby, P. 2019. Split spawning increases robustness of coral larval supply and inter-reef connectivity. Nat. Commun., 10:3463. doi: 10.1038/s41467-019-11367-7

Hutchings, P.A. \& Howitt, L. 1988. Swarming of polychaetes on Great Barrier Reef. Proc. 6th Int. Coral Reef Sym. Townsville, 8-12 August 1988.

Jekti, D.S.D., Yulianti, E., Suryawati, H., Maswan, M. \& Kastoro, W. 1993. Polychaete diversity in Lombok Island and Bau nyale tradition. Jurnal IImu-IImu Perairan dan Perikanan Indonesia, 1(1): 21-32. [Indonesian]

Lefale, P.F., 2010. Ua 'afa le aso stormy weather today: traditional ecological knowledge of weather and climate. The Samoa experience. Climatic Change, 100(2):317-335. doi: 10.1007/s10584-009-9722-z

Mahulette, F. 2020. Traditionally catching and processing of laor in Moluccas Islands. Local Wisdom: Jurnal IImiah Kajian Kearifan Lokal, 12(2):99-110. doi: 10.26905/Iw.v12i2. 4078

Nozawa, Y. 2012. Annual variation in the timing of coral spawning in a high-latitude environment: Influence of temperature. Biol. Bull., 222:192202. doi: 0.1086/BBLv222n3p192

Odani, S., Furusawa, T., Sato, M. \& ShimizuFurusawa, H. 2016. Ecological anthropological analysis of nyale foraging and the Sasak calendar system in Lombok. Proc .7th Indones. Jpn. Joint Sci. Symp. Chiba, 20-24 November 2016.

Osafune, S., Kouketsu, S., Masuda, S. \& Sugiura, N. 2020. Dynamical ocean response controlling the 
eastward movement of a heat content anomaly caused by the 18.6-year modulation of localized tidally induced mixing. J. Geoph. Res. Oceans, 125(2): e2019JC015513. doi: 10.1029/ 2019JC015513

Pamungkas, J. 2015. Species richness and macronutrient content of wawo worms (Polychaeta, Annelida) from Ambonese waters, Maluku, Indonesia. Biodiv. Data J., 3:e4251. doi: 10.3897/bdj.3.e4251

Pamungkas, J. \& Glasby, C.J. 2019. Status of polychaete (Annelida) taxonomy in Indonesia, including a checklist of Indonesian species. Raffles Bull. Zool., 67:595-639. doi: 10.26107/RBZ2019-0045

Peng, D., Hill, E.M., Meltzner, A.J. \& Switzer, A.D. 2019. Tide gauge records show that the 18.61year nodal tidal cycle can change high water levels by up to $30 \mathrm{~cm}$. J. Geoph. Res. Oceans, 124(1):736-749. doi: 10.1029/2018J C014695

Prentiss, N.K. 2020. Nocturnally swarming Caribbean polychaetes of St. John, US Virgin Islands, USA. Zoosymposia, 19(1):91-102. doi: 10.11646/ zoosymposia.19.1.12

Sakai, Y., Hatta, M., Furukawa, S., Kawata, M., Ueno, N. \& Maruyama, S. 2020. Environmental factors explain spawning day deviation from full moon in the scleractinian coral Acropora. Biol. Lett., 16:20190760. doi: 10.1098/rsbl.2019.0760

Shlesinger, T. \& Loya, Y. 2019. Breakdown in spawning synchrony: A silent threat to coral persistence. Science, 365(6457):1002-1007. doi: 10.1126/science.aax0110

Taqwiem, A., Muhammad, H.A.R. \& Maulidi, A. 2020. Halal tourism development analysis in Lombok Island. International Conference on Islam, Economy, and Halal Industry. KnE Soc. Sci., 4(9):177-184. doi: 10.18502/kss.v4i9.7324

Triyanti, R., Kurniasari, N., Yuliaty, C., Muawanah, U. \& Febrian, T. 2020. Management of coastal resources in Mandalika in an era of disruptive innovation waves. IOP Conf. Ser.: Earth Environ. Sci., 584(1):012064. doi: 10.1088/1755-131 $5 / 584 / 1 / 012064$
Tsumura, S. 2012. Adjusting calculations to ideals in the Chinese and Japanese calendars. In: BenDov, J., Horowitz, W., Steele, J.M. (eds.). Living the Lunar Calendar. Oxbow Books, Oxford. pp. 349-372.

Vélez-Arellano, N., Valenzuela-Quiñonez, F., GarcíaDomínguez, F.A., Lluch-Cota, D.B., GutiérrezGonzález, J.L. \& Martínez-Rincón, R.O. 2020. Long-term analysis on the spawning activity of green (Haliotis fulgens) and pink (Haliotis corrugata) abalone along the central west coast of Baja California. Fish. Res., 228:105588. doi: 10.1016/j.fishres.2020.105588

Wijayanti, D.P., Indrayanti, E., Wirasatriya, A., Haryanto, A., Haryanti, D., Sembiring, A., Fajrianzah, T.A. \& Bhagooli, R. 2019. Reproductive seasonality of coral assemblages in the Karimunjawa Archipelago, Indonesia. Front. Mar. Sci., 6:195. doi: 10.3389/fmars. 2019.00195

Willis, B.L., Babcock, R.C., Harrison, P.L., Oliver, J.K. \& Wallace, C.C. 1985. Patterns in the mass spawning of corals on the Great Barrier Reef from 1981 to 1984. Proc. 5th In.t Coral Reef Cong., Tahiti, 27 May -1 June 1985.

Willis, B.L., van Oppen, M.J., Miller, D.J., Vollmer, S.V. \& Ayre, D.J. 2006. The role of hybridization in the evolution of reef corals. Annu. Rev. Ecol. Evol. Syst., 37:489-517. doi: 10.1146/annurev.ecol sys.37.091305.110136

Wolstenholme, J., Nozawa, Y., Byrne, M. \& Burke, W. 2018. Timing of mass spawning in corals: potential influence of the coincidence of lunar factors and associated changes in atmospheric pressure from northern and southern hemisphere case studies. Invertebr. Reprod. Dev., 62(2):98-108. doi: 10.1080/07924259. 2018.1434245

Yamano, H., Sakuma, A. \& Harii, S. 2020. Coral-spawn slicks: Reflectance spectra and detection using optical satellite data. Remote Sens. Environ., 251:112058. doi: 10.1016/j.rse.202 0.112058

Yasuda, I. 2018. Impact of the astronomical lunar 18.6-yr tidal cycle on El-Niño and Southern Oscillation. Sci. Rep., 8(1):1-7. doi: 10.1038/ s41598-018-33526-4 